\title{
Medykalizacja męskiej seksualności
}

\author{
Urszula Kluczyńska \\ Uniwersytet Medyczny im. K. Marcinkowskiego w Poznaniu
}

Artykuł przybliża problematykę procesu medykalizacji seksualności mężczyzn. W ramach tekstu opisałam zjawisko medykalizacji, skupiając się przede wszystkim na medykalizacji seksualności. Scharakteryzowałam proces medykalizacji homoseksualności i transseksualności. Wskazałam, w jaki sposób medycyna kontroluje i normalizuje seksualność, oraz jak ją wyjaśnia i jakie rozwiązania "problemów” związanych z seksualnością proponuje. Odniosłam się do sposobu, w jaki dyskurs medyczny kontroluje męskie ciała i seksualności, a także wskazałam, jak dochodzi do redukowania rozumienia seksualności do praktyk seksualnych i falliczności. W artykule próbowałam odejść od - wspieranego przez dyskurs medyczny heteronormatywnego sposobu postrzegania seksualności i przyjrzeć się konstruowaniu seksualności mężczyzn homoseksualnych i transseksualnych w kontekście procesu medykalizacji. Trudnością okazało się jednak samo uwikłanie w dyskurs medyczny, odniesienie do ustalonym "norm” i stosowanie określeń, które wykorzystuję w poniższych analizach, a które są terminami tegoż dyskursu.

From sex to food, from aspirins to clothes, from driving your car to ride the surf, it seems that under certain conditions or in combination with certain other substances or activities or if done too much or too little, virtually anything can lead to medical problems. (Zola 1982)

\section{Wstęp}

Odniesienie się do seksualności mężczyzn wzmacnia porządek heteronormatywny, jeśli w zamyśle czyniony jest podział na mężczyzn i kobiety jako jedynej słusznej relacji seksualnej. Posługując się tym terminem, korzystam jednak z niego jako powszechnie stosownego, choć nie ukrywam, że sprawia mi on kłopot. Pisząc "mężczyzna”, wydzielam jednostki, które są w jakiś sposób definiowane i definiują siebie. Chciałabym pojęcie "mężczyźni” odnieść do osób, które same o sobie myślą i mówią w ten sposób, a zatem do osób, którym to określenie mężczyzna. Do osób, które w dowolny sposób opisują lub identyfikują się z jakimiś męskościami, choć mam świadomość, że i w to zestawienie wkrada się hierarchia, jaka jest w porządku genderowym. Wykorzystanie terminu „mężczyzna” w kontekście seksualności, nawet w liczbie mnogiej - dla podkreślenia wielości 
sposobów na bycie mężczyzną - nie zmienia faktu, że oznacza wsparcie heteronormatywnego porządku, który nigdy tak naprawdę nie został zachwiany. Także określenia, które wykorzystuję w poniższych rozważaniach, jak: homoseksualność czy heteroseksualność, wspierają dyskurs medyczny, ponieważ są terminami tegoż dyskursu. Trudno też, mino próby przyjęcia autodefinicji męskości, wyjść poza heteronormatywność w kontekście medykalizacji seksualności, gdyż dyskurs medyczny usilnie traktuje jako normę to, co jest raczej możliwością, opcją. Wyjście poza jedyne słuszne męskie ciało, jedyną słuszną seksualność (sprowadzaną zwykle do praktyk seksualnych) okazuje się być trudne, gdyż dyskurs medyczny patologizuje lub pomija milczeniem wszystko, co nie zawiera się w medycznym standardzie. Rozwiązaniem może być pomijanie normy, odejście od medycznych definicji, co jednak nie pozwala podjąć dialogu z perspektywą medyczną. Pojawia się pytanie: Czy taki dialog jest możliwy? Czy możliwe jest tylko krytyczne odczytywanie medycznych opisów i norm lub analiza sposobu, w jaki medyczny dyskurs wzmacnia wprowadzone przez siebie standardy? Mam zatem ogromną wątpliwość - odnosząc się do analiz związanych z medykalizacją seksualności - czy korzystanie z języka medycznego, założeń medycznych i norm zbytnio nie więzi mnie w medycznej pespektywie, gdyż brakuje tam kategorii, które nie patologizują, pokazują różnorodność, a nie odmienność (od normy). Perspektywa medyczna w kwesti seksualności mężczyzn odnosi się do heteronormatywnego porządku, pomija inne opcje, które tym sposobem znikają. W dyskursie medycznym seksualność rozważana jest przede wszystkim z perspektywy osób cispłciowych, utożsamiana z praktykami heteroseksualnymi, koncentruje się na możliwościach, satysfakcji i sposobach realizacji stosunku seksualnego. W kontekście powyższych wątpliwości i ograniczeń zdecydowałam się zatem skupić na sposobie, w jaki dyskurs medyczny opisuje męską seksualność, by wskazać braki, a tym samym drogi uzyskiwania władzy nad ciałem i seksualnością, które definiuje jako męskie.

\section{Medykalizacja codzienności}

Medykalizacja to termin opisujący proces, w ramach którego niemedyczne problemy definiuje się i traktuje jak medyczne, określa się je mianem choroby lub zaburzenia ${ }^{1}$, a w związku z tym poddaje leczeniu (Conrad 1992: 209). Proces medykalizacji przyczynia się do utożsamienia zaburzenia z chorobą, zwłaszcza w rozumieniu potocznym, przez co szereg zaburzeń jest traktowanych jak choroba lub wręcz w ten sposób promowanych, przez co oczekuje się ich leczenia. Medykalizacja

\footnotetext{
${ }^{1}$ Szerzej na temat różnicy i problemów definicyjnych związanych terminem choroba i zaburzenie na przykładzie problematyki psychicznej zob. Stanisław Pużyński (2007).
} 
nie jest jednak wyłącznie zjawiskiem, w którym dochodzi do "uczynienia czegoś medycznym", ma szersze znaczenie, a sam termin nie ma neutralnego charakteru, lecz odnosi się do krytyki zjawiska. Talcott Parsons (2009), który jako pierwszy umiejscowił medycynę w szerszym kontekście społecznym i zainspirował do pogłębiania analizy zjawiska Eliota Freidsona (1970a, 1970b) i Irvinga Zolę (1972), określił medycynę jako instytucję kontroli społecznej. Według Zoli medykalizacja to „proces, w wyniku którego coraz więcej elementów codziennego życia podlega medycznej władzy, wpływowi i nadzorowi" (Zola 1983: 210). Charakteryzując zjawisko medykalizacji należy podkreślić, że kluczowe w tym procesie jest definiowanie problemu z wykorzystaniem terminów medycznych, stosowanie medycznego języka do opisu owego problemu, wykorzystanie medycznego podejścia do zrozumienia specyfiki problemu lub zastosowanie medycznych form interwencji, by "leczyć" problem. Medykalizacja może obejmować trzy sfery: pojęciową, instytucjonalną oraz interakcyjną. Sfera pojęciowa dotyczy stosowania medycznego języka lub modelu do opisu niemedycznego problemu. Poziom instytucjonalny dotyczy zastosowania przez organizacje medycznego podejścia do realizacji własnych celów, co daje lekarzom możliwość kierowania niemedycznym personelem (Maturo 2012: 123). Z kolei poziom interakcyjny odnosi się do relacji lekarz-pacjent, kiedy to lekarz definiuje problem jako medyczny, stawia diagnozę lub traktuje dany problem społeczny jako medyczny, zalecając medyczne rozwiązania (Conrad 1992: 211).

W odniesieniu do medykalizacji istotne są zjawiska, które nakreślają kontekst rozwoju procesu, czyli sekularyzacja oraz zmiana statusu medycznej profesji. Jak zauważa Peter Conrad (1992: 213), wielu badaczy wskazuje, że we współczesnych społeczeństwach medycyna zastąpiła religię, pełniącą wcześniej rolę dominującej ideologii moralnej oraz instytucji kontroli społecznej. Medycyna, jako dominujący dyskurs naukowy, który normalizuje, ujarzmia i reguluje stała się podstawą polityki nazwanej przez Michaela Foucaulta (1998) biopolityką. Zdaniem tego filozofa, „oparte na biowładzy techniki kontroli i nadzoru sprawiają (...), że regulacja życia odbywa się już nie poprzez dyscyplinę, lecz normalizację i narzucenie wzorów typizacji. Będąc elementem polityki państwa, biowładza staje się tym samym podstawą biopolityki, której celem jest kontrola społeczna poprzez zapewnienie higieny publicznej, koordynowanie sposobów leczenia, centralizację informacji, normalizację wiedzy i nauczania higieny oraz medykalizację stanów niepożądanych" (Domaradzki 2007: 465).

Conrad (2005: 5) wskazuje również na współczesne "machiny medykalizacji”, czyli biotechnologię, konsumentów i zarządzanie opieką. Badacz podkreśla zmianę leżącą u podstaw medykalizacji, a 
mianowicie fakt, że jest ona coraz bardziej sterowana przez rynek (Conrad 2006: 19). Istotną rolę w procesie medykalizacji odgrywają firmy farmaceutyczne, dla których wypromowanie zaburzenia lub choroby jest sposobem rozwoju rynku dla produktu stanowiącego remedium na dany problem (Busfield 2010; Bell, Figert 2012; Tiefer 2000). Należy jednak podkreślić, że medykalizacja nie jest tożsama z farmaceutykalizacją, czyli „procesem, w którym społeczne, behawioralne i fizyczne choroby podlegają leczeniu lub uznawane za wymagające leczenia/interwencji, przez zastosowanie farmaceutyków przez lekarzy, pacjentów" (Abraham 2010: 290), gdzie przemysł farmaceutyczny promuje zbędne leczenie, testy i diagnozy w celu sprzedaży produktów (Welch, Schwartz, Woloshin 2011). Kluczowe dla procesu medykalizacji stało się przekształcenie pacjenta w konsumenta, który może dążyć do diagnozy i określonego procesu leczenia. Pod wpływem programów telewizyjnych, reklam, informacji zaczerpniętych z internetu ludzie stosują bowiem terminologię medyczną w celu opisu swojego stanu zdrowia, dokonując autodiagnozy (Barker 2009: 100). Mimo iż rola lekarzy w procesie medykalizacji zmniejszyła się, to jednak nadal - choć w inny sposób - włączeni są w ten proces. Lekarze postrzegają jako element swej lekarskiej misji zmniejszenie cierpienia ciała i duszy, czyli przykładowo uzasadniają leczenie hormonem wzrostu niskich dzieci, by te nie były stygmatyzowane ze względu na swój niski wzrost (Conrad 2006: 20). Badacze i badaczki zwracają również uwagę, że w związku z rozwojem biomedycyny, techniczno-naukowych innowacji oraz komercjalizacji natury medykalizacji możemy mówić dziś raczej o biomedykalizacji (Clarke, Shim, Mamo, Fosket, Fishman 2003).

Do medykalizacji dochodzi, gdy podejście medyczne zostaje wykorzystane do wyjaśniania lub definiowania problemu, przykładem może być "dysforia na tle tożsamości płciowej" (transseksualizm), homoseksualizm, impotencja, jak również otyłość, hiperaktywność, bezpłodność, alkoholizm. Medykalizowanych jest wiele "naturalnych procesów życiowych", jak seksualność, starzenie się, poród czy śmierć (Conrad 1992: 213). W większości przypadków medykalizacja nie jest jednak procesem kompletnym, skończonym, w związku z czym Conrad proponuje, by mówić raczej o stopniach medykalizacji danego problemu. Pewne zjawiska są bardzo zmedykalizowane, jak na przykład poród lub śmierć, podczas gdy inne częściowo (np. menopauza), a jeszcze inne minimalnie (np. uzależnienie od seksu) (Conrad 1992: 220). Według Conrada medykalizacja jest dwukierunkowa. Można zatem mówić o demedykalizacji, a zatem procesie odwrotnym, polegającym na tym, że dany problem przestaje być określany za pomocą medycznych definicji (Conrad 1992: 224). Takim przykładem może być masturbacja, która była kiedyś postrzegana jako 
choroba wymagająca leczenia (Engelhardt 1974) lub homoseksualizm. W literaturze przedmiotu można znaleźć współczesne podejścia, które wskazują, że w zależności od kryterium dane zjawisko w różnych wymiarach raz może wydawać się zmedykalizowane, a raz zdemedykalizowane (Halfmann 2011, Wieczorkowska 2013: 116, 128-130).

\section{Tabela 1. Poziomy i wymiary medykalizacji i demedykalizacji w koncepcji Drew Halfmanna}

\begin{tabular}{|c|c|c|}
\hline Makro & Mezo & Mikro \\
\hline $\begin{array}{l}\text { Ustawodawstwo, raporty, } \\
\text { regulacje, } \\
\text { debaty organizacji krajowych } \\
\text { i międzynarodowych (rządy, } \\
\text { sądy, korporacje, } \\
\text { uniwersytety, } \\
\text { rynki, fundacje, media, } \\
\text { czasopisma, } \\
\text { organizacje non profit. }\end{array}$ & $\begin{array}{l}\text { Misje, raporty, reklamy, } \\
\text { procedury } \\
\text { lokalnych i regionalnych } \\
\text { organizacji, takich jak: zakłady } \\
\text { pracy, szpitale, } \\
\text { grupy medyczne, kliniki, domy } \\
\text { seniora, } \\
\text { szkoły, ośrodki pomocy } \\
\text { społecznej, } \\
\text { więzienia. }\end{array}$ & $\begin{array}{l}\text { Interakcja twarzą } \\
\text { w twarz, fizyczny } \\
\text { kontakt między dostawcami } \\
\text { a klientami. } \\
\text { Samozarządzanie. }\end{array}$ \\
\hline \multicolumn{3}{|c|}{$\begin{array}{l}\text { Dyskursy } \\
\text { Biomedyczne słownictwo, modele i definicje - symptom, choroba, zarażenie }\end{array}$} \\
\hline \multicolumn{3}{|c|}{$\begin{array}{l}\text { Praktyki } \\
\text { Biomedyczne praktyki i technologie - testowanie, mierzenie, normalizacja, nadzór, szacowanie } \\
\text { ryzyka, pokrycie w polisie ubezpieczeniowej, badanie, testy laboratoryjne, diagnostyka obrazowa, } \\
\text { higiena, operacja, leki, narzędzia medyczne }\end{array}$} \\
\hline \multicolumn{3}{|c|}{$\begin{array}{l}\text { Jednostki i aktorzy } \\
\text { Jednostki i zbiorowi biomedyczni aktorzy - lekarze, badacze, szpitale, agencje ubezpieczeniowe, } \\
\text { grupy medyczne, producenci leków i urządzeń medycznych, szkoły medyczne, organizacje } \\
\text { i stowarzyszenia zawodowe }\end{array}$} \\
\hline
\end{tabular}

Źródto: Halfmann 2011 za: Wieczorkowska 2013 s. 128.

\section{Medykalizacja seksu}

"Medykalizacja seksu" jest sformułowaniem stosowanym często w wymiarze krytycznym, a dotyczącym biomedycznego języka, sposobu wyjaśniania i proponowanych rozwiązań "problemów" związanych z seksualnością (Tiefer 2012).

Leonore Tiefer (1996: 252-282) wskazała na kilka filarów medycznego modelu, który znalazł swe odbicie w sposobie postrzegania i analizowania seksualności. Przede wszystkim podkreśliła wpływ kartezjańskiego podziału na ciało i umysł, gdzie metafora oddzielonego od ducha ciała, porównanego do maszyny, odgrywa kluczową rolę w procesie medykalizacji seksualności. Takie 
podejście powoduje koncentrację na dysfunkcjach seksualnych, które zaburzają akt seksualny i odnosi się do działań seksualnych w kontekście fizjologicznego funkcjonowania. Mimo odejścia od dualistycznego podziału człowieka, cień tej perspektywy pokutuje traktowaniem aktywności seksualnych jako cielesnych, związanych z biologicznym działaniem, z obiektywnie ustalonymi normami i standardami. Przykładem może być kwestia erekcji, którą odnosi się do pewnej normy, którą można zmierzyć, a dysfunkcję poddać leczeniu. Również naturalizm, a zatem tłumaczenie rzeczywistości poprzez odniesienie do świata przyrody, a w kontekście seksualności do świata zwierząt (Kinsey, Pomeroy, Clyde 1948) otworzył drzwi medykalizacji seksualności. Postrzeganie seksualności jako obiektywnego i materialnego - czyli cielesnego - produktu ewolucji odcisnęło swe piętno na języku, który stosowany jest przez współczesną seksuologię. Masters i Johnson (1966), choć zmienili obiekt badań ze zwierząt na ludzi, to jednak utwierdzili się w przekonaniu o istnieniu uniwersalnej seksualności, związanej głównie z cielesnością, i uniwersalnej biologicznej normy, a co za tym idzie - listy zaburzeń. Tiefer wskazuje również na znaczenie indywidualizmu $\mathrm{w}$ procesie medykalizacji seksualności. W medycznym modelu problem seksualny dotyczy jednostki i to ona jest oceniana i leczona. Pomijane jest znaczenie otoczenia. Kolejnym filarem medycznego modelu jest redukcjonizm biologiczny, którego efektem jest zagubienie kontekstu postrzegania zjawisk. Istotny wpływ ma również reifikacja. Pacjent udający się do specjalisty nie dowie się, co się dzieje, gdyż lekarz sprawdzi tylko, czy choroba ma miejsce. Pacjentowi może zatem zostać postawiona diagnoza przedwczesnej ejakulacji i zapisane leki, ale dany problem nie zostanie odniesiony do sytuacji życiowych, kultury czy indywidualnej historii (Tiefer 1996: 252-282).

Zjawisko medykalizacji seksualności ma swe źródła w początku dziewiętnastego wieku, kiedy to wiele problemów uzyskało miano chorób i zaburzeń (Conrad, Schneider 1992). Od tego czasu nauka i medycyna podjęła liczne próby ilościowego opisu, zdefiniowania, kategoryzacji seksualności przy użyciu wielu narzędzi pomiaru i praktycznych teorii. Szereg kwestii związanych z seksualnością zaczęto tłumaczyć biologicznie poprzez instynkt, hormony, neuroprzekaźniki lub geny, a wśród metod badawczych - poza klinicznymi studiami przypadku - dominowały badania ilościowe. Medykalizacja seksualności wiązała się między innymi z rozpowszechnieniem farmaceutycznych rozwiązań na "nowe choroby” (przykładem może być sukces Viagry), wzrostem zabiegów z zakresu chirurgii kosmetycznej narządów płciowych, szybkim rozpowszechnieniem produktów antykoncepcyjnych, umożliwieniem reprodukcji osobom z niepełnosprawnościami, czy 
podejmowaniem operacji związanych z korektą płci biologicznej. Krytyka procesu medykalizacji seksualności przyczyniła się do dyskusji nad kwestiami związanymi z: koncentracją na genitaliach, co łączy się z androcentryzmem; standaryzacji seksualności i pojawiania się w związku z tym nowych form wstydu; zaniedbaniami psychospołecznych wymiarów seksualności, jak wpływu na kształtowanie przyjemności seksualnej, dobrego samopoczucia, czy praktyk oraz norm; oraz jatrogennego ryzyka zdrowotnego i efektów ubocznych wynikających z medycznego leczenia problemów seksualnych (Cacchioni, Tiefer 2012: 308).

\section{Seksualność i norma}

Jak podkreśla Tiefer (1996: 263) centralnym elementem biomedycznego modelu jest norma, która stanowi swoistą linię demarkacyjną - oddziela dobro i zło w świecie medycyny. Diagnoza polega na poszukiwaniu nieprawidłowości, zaburzeń i bazuje na „obiektywnych standardach". W odniesieniu do normy związanej z seksualnością to seksuologia - jako nauka o seksualności - jest obszarem, w którym określa się normę na podstawie wyników naukowych badań klinicznych i prezentuje szereg klasyfikacji będących postawą do diagnozowania zaburzenia. Medyczny model określa normę jeśli chodzi o działanie poszczególnych części ciała i ich właściwe funkcjonowanie. Zakłada też, że poszczególne części ciała, a także cały organizm, który został stworzony przez naturę w procesie ewolucji - głównie w celu przetrwania i reprodukcji - powinny spełniać zakładane funkcje i być wykorzystywane w "naturalny" sposób. Tak więc każde użycie ciała "wbrew naturze” łączy się z patologizowaniem danego zachowania, krytykowane są zatem liczne "nienaturalne" zachowania seksualne (Tiefer 1996: 263).

Aktywność i doświadczenia seksualne są inwigilowane i dyscyplinowane przez trening społeczny związany z myśleniem według "seksualnej normy” odnoszonej do fantazji, pożądania, obiektów pożądania, aktywności i tożsamości (własnej i innych) traktowanej jako normalna lub niezdrowa, czyli właściwy seks kontra perwersje seksualne, niedobór kontra nadmiar (Tiefer 2012: 312). Medykalizacja męskiej seksualności jest procesem, który określa jej wybrane elementy i potencjał reprodukcyjny jako mieszczące się w medycznej normie (jedyna właściwa erekcja, jedyna właściwa ejakulacja połączona z orgazmem, jedyna słuszna częstość pożądania i rodzaj obiektu pożądania) i nazywa tę normę naturalną, uniwersalną i wystarczającą dla właściwego seksualnego zachowania i doświadczania (Tiefer 2001: 89). Dominujący medyczny model promuje bowiem konkretne normy seksualności, które związane są zwykle ze sprawnością narządów płciowych. W efekcie procesu 
medykalizacji seksualności jako niezbędne elementy udanego doświadczenia seksualnego określone zostały: pożądanie, pobudzenie narządów płciowych, a także następujący w odpowiednim momencie orgazm. Medykalizacja seksualności przyczynia się zatem do redukowania seksualności do praktyk seksualnych.

Jako najsłuszniejszą i naturalizowaną wersję kontaktu seksualnego dyskurs medyczny określił seks heteroseksualny, definiowany jako penetracja pochwy przez penisa. To penetracja waginy przez penisa jest określana jako „prawdziwy seks”, a seks oralny, masturbacja, dotyk, pocałunki są określane jako „czynności wstępne” poprzedzające "właściwy seks" (Jackson 1984: 44 za: Potts 2002: 34). Takie definiowanie kontaktu seksualnego wzmacnia heteronormatywny i "androcentryczny model seksualności" (Maines 1999: 5), gdzie penetracja i męski orgazm stanowi warunek konieczny, by daną aktywność nazwać seksem. Ponadto perspektywa biologiczna łączy seks przede wszystkim z prokreacją, a zatem normatywizuje udział kobiety i mężczyzny w tej aktywności, wykluczając inne relacje, oraz podkreśla w owym układzie dominację mężczyzny (Plummer 2005: 181). Dążenie do kontaktu seksualnego, określanego prawie wyłącznie jako stosunek seksualny (stosunek waginalny), traktowane jest w biomedycznym podejściu jako naturalne, wynikające z ludzkiej (męskiej) natury. Jak zauważa James Messerschmidt (1993: 90), normatywna męska seksualność jest konstruowana w ramach praktyki określającej mężczyzn jako osoby o niekontrolowanych i niepohamowanych żądzach. Męska seksualność jest zwykle opisywana jako naturalna, niedająca się opanować, skoncentrowana na penisie i osiąganiu orgazmu (Plummer 2005: 175), którego osiągnięcie jest traktowane w dyskursie medycznym jako wyznacznik umiejętności seksualnych i wskaźnik zdrowia seksualnego (Potts 2002: 73). Seks - rozumiany najczęściej jako penetracja pochwy przez penisa, zakończona wytryskiem, co podkreśla prokreacyjny wymiar tej aktywności - jest w przekonaniu mężczyzn jednoznaczny z erekcją, która według większości jest warunkiem koniecznym, by w ogóle mówić o doświadczeniu seksu (Potts 2002: 138).

Paul Robinson (1976) dostrzegł, że do końca dziewiętnastego wieku analizy medyczne związane z seksualnością koncentrowały się przede wszystkim na nadmiarze, a zatem nadmiernym pożądaniu czy masturbacji. Wiek dwudziesty przyniósł zmianę i problemem stała się słabość, brak, niewystarczające pobudzenie czy pożądanie, niewystarczający wzwód. W związku z tym interwencje medyczne wiązały się głównie z psychoedukacją, działaniami dążącymi raczej do pobudzania i odblokowania niż tłumienia i hamowania (Tiefer 2012: 315). Dążenie do pobudzania doczekało się 
"farmaceutycznych rozwiązań" w celu medycznego "naprawienia” patologii, a zatem leczenia. Przykładem może być kwestia impotencji, która w przeszłości była traktowana jako niemile widziane doświadczenie, osobisty problem, a nawet znak perwersji. Wynalezienie "impotenta" przez dyskurs naukowy dziewiętnastego wieku spowodowało, że termin ten został połączony z patologicznym stanem związanym z jednostkową tożsamością i stał się czynnikiem różnicującym (Wienke 2006: 47). Patologizowanie problemów z erekcją jest przykładem na to, w jaki sposób instytucje naukowe i medycyna medykalizują i kontrolują męskie ciało oraz seksualność (Foucault 2000). Impotencja jest dziś najczęściej postrzegana jako psychologiczna lub psychiczna choroba wymagająca działań medycznych (Wienke 2006: 47). Nazwanie kogoś impotentem stygmatyzuje, „jeżeli mężczyzna usłyszy od swojego lekarza, że jest impotentem lub gdy zwraca się do swojej partnerki i mówi, że jest impotentem: mówi coś więcej niż tylko to, że jego penis nie może osiągnąć erekcji" (Kelly 1981: 126 za: Tiefer 1989: 165). Etykietka impotenta odzwierciedla istotny moment w społecznej konstrukcji męskiej seksualności (Tiefer 1989: 166). Jeśli mężczyźnie zdarzy się problem z erekcją, może mieć poczucie zagrożenia swej męskości i obawiać się, że jego seksualność jest nienaturalna i odbiega od normy. W toku socjalizacji mężczyźni dowiadują się, że stosunek seksualny (z kobietą) jest najistotniejszym elementem aktywności seksualnej, a od mężczyzny oczekuje się seksualnej potencji i możliwości osiągania erekcji, tak więc kulturowe normy męskości w połączeniu z fallocentryczną konstrukcją seksualności także przyczyniają się do medykalizacji impotencji (Wienke 2006: 49). Z drugiej strony medykalizacja impotencji daje mężczyźnie naukowe („obiektywne”) wyjaśnienie jego problemów, zmniejsza kulturową stygmatyzację, uwalnia mężczyznę od poczucia winy i poczucia indywidualnej klęski w obliczu problemów z potencją (Tiefer 1994: 363-377).

"Wynalezienie" i „rozpowszechnienie” impotencji jest ściśle związane z rozwojem rynku farmaceutycznego. Impotencja została określona jako problem medyczny zanim pojawiła się Viagra, ale to firma farmaceutyczna Pfizer wypromowała zaburzenie erekcji, by powstał rynek dla produktu (Conrad 2006: 19). "Leki na potencję” można traktować w kategorii wyzwolenia naprawiania męskości, ale również poddania kontroli coraz większych obszarów życia społecznego (Loe 2001). Leki poprawiające wydolność seksualną mężczyzn odnoszą się nie tylko do kwestii seksualności, lecz również rekonstruowania procesu starzenia się jako problemu medycznego. Starość, w tym kwestie związane z potencją, można leczyć (MacDougall 2006: 60), a sprawność seksualna w każdym wieku stała się normą, z kolei brak sprawności - patologią (Marshall, Katz 
2002). W kontekście seksualności mężczyzn norma dotyczy nie tylko oczywistości pożądania i dążenia do seksu przez mężczyzn, ale także z funkcjonowaniem ciała, a przede wszystkim penisa, którego posiadanie z perspektywy medycznej jest warunkiem koniecznym, by móc określić daną osobę mianem mężczyzny. Metafora ciała jako maszyny, ściśle związana z dyskursem medycznym, wykorzystywana jest również do opisu optymalnego kontaktu seksualnego. Penis jest elementem, który - gdy zawodzi - należy naprawić, by tym samym naprawić męskość. W wyniku wprowadzenia leków, które przekraczają granice wieku czy możliwości ciała, pojawia się „nadnormalność", która szybko staje się standardem. Wzwód oczekiwany przez siedemdziesięciolatka nie jest odnoszony do możliwości osób w tym wieku, ale do standardu uzyskanego z farmaceutycznym wsparciem, który staje się oczekiwaną normą w każdym wieku. W wyniku procesu medykalizacji seksualności sprawność seksualna w każdym wieku stała się nie tylko możliwością, stała się obowiązkiem.

Zdaniem Jonathana Katza (1995: 121) proces medykalizacji seksualności przyczynił się do tego, że heteroseksualność została określona jako norma, patologizując inne formy kontaktu seksualnego i przesunęła na margines homoseksualność i biseksualność, czyniąc je "gorszymi”. Męskie ciało stało się ciałem ze "sprawnym" (w kategoriach medycznych) penisem, który stał się symbolem różnicy, wyższości i władzy. Tym sposobem wyklucza się poza normę ciała niejednoznacznie męskie, ciała męskie bez penisa, ciała męskie bez „właściwie” działającego penisa, czy osoby niedążące do penetracji. Ponadto argumentem wieńczącym ustalenie heteroseksualnego kontaktu jako „Właściwego i dobrego" stało się dążenie do reprodukcji, uzasadniające seksualną przyjemność (Murphy 2002: 99).

Konsekwencją biomedycznego modelu interpretacji zachowań seksualnych jest przede wszystkim patologizowanie tych, które wymykają się medycznej normie, są one nie tylko poza normą, są one również zostają określone jako „złe”. Bycie „normalnym” w sferze seksualnej jest bowiem postrzegane nie tylko w wymiarze zdrowia fizycznego i psychicznego, a także osądu moralnego.

\section{Seks jako zdrowie}

Medykalizacja seksu związana jest patologizowaniem pewnych form i częstości aktywności seksualnej. Judy Segal (2012: 369) zwraca uwagę na utożsamianie dobrego seksu z dobrym zdrowiem. Seks jest promowany jako zdrowy sam w sobie, przywracający i wzmacniający zdrowie, podczas gdy brak seksu jest traktowany jako problem. Seks promowany jest przykładowo jako 
sposób na zmniejszenie ryzyka zachorowania na raka prostaty (Regal 2012: 370). Kristina Gupta (2011: 127) wskazuje, że seks jest traktowany jako element promocji zdrowia i rodzaj obowiązku. Zdaniem badaczki, określanie seksu jako czynności „prozdrowotnej” może, co prawda, przyczynić się w pewnych przypadkach do zniesienia piętna towarzyszącego aktywności seksualnej, ale z drugiej strony może skutkować wzrostem presji, by być aktywnym seksualnie, a także patologizować seksualne "dysfunkcje”. Aseksualność może zostać zatem traktowana jako choroba lub dysfunkcja zgodnie z założeniem, że pożądanie seksualne jest uniwersalne, a jego brak jest odzwierciedleniem patologii lub powoduje krzywdę (Kim 2010: 159). Aktywność seksualna jest postrzegana również jako element pomyślnego starzenia się (Marshall 2012: 338). Powszechnie funkcjonujące przekonania stawiające znak równości miedzy sprawnością seksualną a poczuciem „prawdziwej męskości” przyczyniają się do ustalenia jednej normy aktywności seksualnej dla okresu starości i dojrzałości utożsamianej ze stosunkiem seksualnym. W związku z tym kłopoty z utrzymaniem lub osiągnięciem wzwodu przez mężczyzn w okresie starości nie są traktowane jako naturalna konsekwencja starzenia, lecz są patologizowane. Osiąganie normy czy zbliżanie się do niej, jest postrzegane jako wyróżnienie się jako osoby „niestarej”, gdyż seksualność jest postrzegana jako „ostateczna granica” pozytywnego starzenia (Kirkman 2005: 340). Osoby, które nie realizują oczekiwań związanych z aktywnością seksualną jako sposobem na dbanie o własne zdrowie mogą odczuwać potrzebę wsparcia farmaceutycznego, by osiągnąć "normę" (Marshall 2012: 339).

\section{Medykalizacja i demedykalizacja męskiej homoseksualności}

Opisane powyżej wątki męskiej seksualności związane są z medycznie ustaloną normą. Norma ta nie tylko opisuje jedyne słuszne męskie ciało, ale również jedynym słuszny kierunek popędu. W procesie konstruowania seksualności mężczyzn istotną rolę odgrywa bowiem opozycja heteroseksualność - homoseksualność. Analizy dotyczące homoseksualności mają wpływ na rozumienie heteroseksualności jako skonstruowanej normy, w odniesieniu do której homoseksualność jest postrzegana jako alternatywa lub odchylenie od normy (Wilkinson i Kitzinger 1994: 308). Jednak „heteroseksualność potrzebuje homoseksualności dla swej własnej definicji: homofobiczny »macho« mężczyzna może definiować siebie jako heteroseksualistę tylko w opozycji do tego, kim nie jest: zniewieściałym mężczyzną homoseksualnym" (Ki Namaste 1996: 202 za: Kochanowski 2004b: 142). 
Medykalizacja homoseksualności jest ściśle związana z procesem medykalizacji seksualności, a zatem sięga końca osiemnastego wieku, rozciągając się przede wszystkim na wiek dziewiętnasty, kiedy to dyskurs naukowy, medyczny, stał się podstawą regulowania i kontrolowania rzeczywistości społecznej (Conrad, Schneider 1992: 211-213). Biblijne interpretacje, choć często wypaczone - jak chociażby niewystępujące w opisie wydarzeń stwierdzenie, że jednym z głównych powodów, który doprowadził do zagłady w Sodomie były zachowania homoseksualne (Conrad, Schneider 1992: 174) - doprowadziły do określenia homoseksualności jako grzechu. Kontakty homoseksualne zostały określone jako grzeszne, ponieważ były niezgodne z jedynym w pełni akceptowym standardem: heteroseksualnym stosunkiem zwieńczonym poczęciem. Zaprzeczały one zatem boskiej intencji i zostały określone jako „nienaturalne”, a ponadto umożliwiały uzyskiwanie przyjemności dla samej przyjemności (Conrad, Schneider 1992: 173-179). W okresie średniowiecza zachowania homoseksualne były nie tylko określane mianem grzechu, ale też poddawane surowej karze jako "zbrodnia przeciwko naturze” (Conrad, Schneider 1992: 212).

Koniec wieku osiemnastego przyniósł kolejne narzędzie definiowania i kontrolowania seksualności - medycynę. Homoseksualizm uległ medykalizacji po części jako odpowiedź na surowe religijne oraz kryminalne sankcje (Greenberg 1998: 406-411), a homoseksualne zachowanie zostało określone nie tylko jako złe, ale również niezdrowe. Koniec dziewiętnastego wieku przyniósł przekonanie, że homoseksualność jest efektem wrodzonej i dziedziczonej słabości, "degeneracji” systemu nerwowego, który jest nieuleczalny oraz nieodwracalny. Osobę homoseksualną uważano za "wybryk natury”, ofiarę, w związku z czym z czasem wycofano się z wcześniejszych praktyk karania ze względu na tę "patologię". Nadszedł czas medycznych diagnoz, publikacji medycznych, leczenia, wzrosło znaczenie psychiatrycznej perspektywy postrzegania homoseksualności. W roku 1952 Amerykańskie Towarzystwo Psychiatryczne zaklasyfikowało homoseksualność jako chorobę (Conrad, Schneider 1992: 179-193). Pojawiły się, co prawda, argumenty, że homoseksualność nie jest patologią, lecz ma charakter organicznej anomalii, co jednak w żadnym stopniu nie zmieniło medycznego paradygmatu postrzegania tej kwestii (Conrad, Schneider 1992: 196). Zmianę przyniosły dopiero działania aktywistów dążących do usunięcia homoseksualności z listy zaburzeń psychicznych (Conrad, Angell 2004: 34). Pojawiły się analizy podkreślające kulturowy wymiar homoseksualności (Conrad, Schneider 1992: 198-199) i ostatecznie, mimo braku zgody co do tego, czym jest homoseksualność, ustalono, że nie jest ona chorobą i nie podlega leczeniu (Conrad, Schneider 1992: 193-199). W roku 1973 Amerykańskie Towarzystwo Psychiatryczne usunęło 
homoseksualność z listy zaburzeń psychicznych (Conrad 1992: 225), tym samym przyznając, że medyczne kryteria nie są odpowiednim narzędziem, by ją opisywać i kontrolować. Jednak Światowa Organizacja Zdrowia (WHO) dopiero w 1990 roku wykreśliła homoseksualizm z Międzynarodowej Statystycznej Klasyfikacji Chorób i Problemów Zdrowotnych. ICD-10 nie opisuje homoseksualizmu i biseksualizmu w kategoriach zaburzeń. Takie posunięcia stały się oficjalnym wyrazem demedykalizacji homoseksualności.

Homoseksualność przestała być definiowana poprzez medyczne terminy z wykorzystaniem medycznych narzędzi, również leczenie medyczne zostało uznane za niewłaściwe działanie. Steven Epstein (2003) uważa jednak, że demedykalizacja jest procesem, który może podlegać kolejnej zmianie i dążenia ruchu LGBT do uznania wyjątkowości problemów zdrowotnych tej grupy, różniących się od heteroseksualnej populacji, mogą przyczynić się do remedykalizacji homoseksualności, gdyż skupiają się na „biologicznych różnicach” (Epstein 2003: 161). Także próby genetycznego wyjaśniania homoseksualności, w ramach współczesnych tendencji do genetyzacji społeczeństwa, mogą otwierać furtkę do remedykalizacji homoseksualności (Conrad, Angell 2004: $36,39)$.

Homoseksualność została wprawdzie zdemedykalizowana (głównie na poziomie makro), ale nie zrehabilitowana (Conrad, Angell 2004: 39). Nie dziwi zatem rezygnowanie $z$ terminu „homoseksualista” na rzecz określenia "gej”, który opisuje raczej styl życia i sposób myślenia o sobie i innych oraz odchodzi od medycznego wymiaru rozumienia terminu "homoseksualność" (Conrad, Schneider 1992: 202). Seksualność geja odnoszona jest często do heteromęskiej relacji seksualnej, gdzie dochodzi do jej pozycjonowania w binarnej relacji dominacji/podporządkowania, aktywności/pasywności. Gej zostaje zatem umiejscowiony przez użycie kalki heteronormy w roli mężczyzny (dominującego, aktywnego) lub kobiety (podporządkowany/pasywny). Gej nie jest jednak kobietą, a Jacek Kochanowski powątpiewa też w to, czy spełnia kulturowe wymogi bycia mężczyzną, pisząc: „mężczyzna to ten, kto pożąda kobiet i rywalizuje z innymi mężczyznami. Gej nie pożąda kobiet, a zamiast rywalizacji z mężczyznami woli seks z nimi. Przestaje zatem wypełniać kulturowe znamiona mężczyzną, przestaje być mężczyzną. Czy staje się tym samym kobietą? Oczywiście nie: nie posiada macicy i odpowiedniego zestawu chromosomów. Kim zatem jest? Z perspektywy kulturowej płciowości: nikim. Naturalnie taki stan nie jest możliwy do zaakceptowania: procedury kulturowego przymusu obligują do bycia albo mężczyzną, albo kobietą. Pozostają zatem 
dwie strategie: albo za wszelką cenę udowodnić sobie i innym, że jednak jestem mężczyzną, albo zbliżyć się w kierunku kobiecości. Pierwszy przypadek to geje ostentacyjnie podkreślający swoją męskość, przywiązanie do piwa i piłki nożnej, szorstkość w obyciu i seksie. Drugi to geje uwielbiający się trochę »poprzeginać«, mówiący o sobie w rodzaju żeńskim" (Kochanowski 2004a: 109). Tak więc zastosowanie heterokalki seksualności, która nagminnie przekładania jest na homoseksualne relacje, pozwoliłaby określić jako mężczyznę tego, który (zawsze) dominuje, (zawsze) penetruje, (zawsze) posiada władzę, nadal jednak nie podlega jednemu wymogowi - nie pożąda kobiety. Tym sposobem wątek pasywności nadal jest obecny w sposobie konstruowania męskości i relacji seksualnej geja. Rafał Majka (2015: 210) prezentując postsubkulturę bareback, pokazuje, jak mężczyźni homoseksualni mogą reinterpretować pasywność w kontaktach seksualnych i wyjść "z heteronormatywnych binarnych ram uległej i »zniewieściałej« pasywności naprzeciw dominującej, męskiej aktywności” (Majka 2015: 210-211). „W dyskursie bareback gej, który przyjmuje w seksie pasywną pozycję, przyjmuje ją zawsze jako (męski) mężczyzna, który w ten sposób wzmacnia oraz potwierdza swoją męskość, odwagę i siłę. Jak zaznacza Dean, »im większa liczba mężczyzn, przez których zostało się analnie spenetrowanym, tym bardziej męskim się jest«. Tak zrekonceptualizowana pasywność jest zupełnym przeciwieństwem zniewieściałej, abiektalnej pasywności, konstruowanej mizoginicznie w dyskursie heteromęskości, którego elementy obecne są również w popularnym dyskursie gejowskich klubów czy portali społecznościowych" (Majka 2015).

Analizowane wcześniej kwestie związane z medycznym postrzeganiem normy seksualności i definiowania seksu mają swe implikacje w sposobie definiowania seksualności mężczyzn homoseksualnych. Mimo demedykalizacji homoseksualności, medyczna norma w powiązaniu ze społeczno-kulturowymi oczekiwaniami wobec męskości przyczynia się do marginalizowania homoseksualności, lub narzucania jej kalki heteroseksualności. Na przestrzeni czasu zmieniało się pojmowanie płci i seksualności człowieka (Meyerowitz 2002). Dyskurs medyczny wytwarza jednak „idealne" ciało męskie, które w tej formie rzadko występuje w rzeczywistości. Dochodzi do umiejscowienia kobiet i mężczyzn na dwóch biegunach podczas, gdy zarówno kobiety, jak i mężczyźni posiadają różne cechy i rzadko są realizacją "typu idealnego". Niektórzy badacze i niektóre badaczki sugerują, że wszyscy są w mniejszym lub większym stopniu fizycznie biseksualni (Meyerowitz 2002: 22). 


\section{Medykalizacja transseksualności}

Współcześni badacze (Stryker 2008b; Valentine 2007) przekonują, że wykreślenie homoseksualności z listy chorób „odbyło się kosztem konceptualnego oddzielenia orientacji seksualnej od tożsamości płciowej i patologizacji transseksualności oraz wymazywania osób niewpisujących się w płciowy binaryzm z historii walki o prawa osób homoseksualnych" (Dębińska 2014: 53).

Podczas gdy osoby homoseksualne nie wykorzystują w sposób szczególny osiągnięć medycznych, osoby transseksualne są uwikłane $\mathrm{w}$ tę zależnościową relację. Ponieważ osoby transseksualne częściej korzystają z medycznych rozwiązań i decydują się na interwencje medyczne, trudniej im wyswobodzić się z władzy medycznego dyskursu, który zawłaszcza sobie prawo do diagnozowania i patologizowania transseksualności. Susan Stryker (2008a) podkreśla, że dostęp do korzystania z usług medycznych przez osoby transseksualne został uzależniony od definiowania transseksualności W kategoriach „zaburzenia”, gdyż tylko „choroba” legitymizuje interwencje medyczne.

\section{Diagnoza patologii - to się leczy}

Podnosząc wątek medykalizacji transseksualności, należy zaznaczyć, że podczas gdy transseksualność ma wymiar historyczny i przeszła wiele ewolucji myślenia w kontekście tożsamości płciowej i towarzyszącej jej tożsamości seksualnej, to jednak medycyna nie była od zawsze jej integralnym elementem. Zmiana nastąpiła w momencie określenia transseksualizmu mianem zaburzenia (ICD-9, jak również ICD-8), przez co stał się on kategorią diagnostyczną. Dziś Międzynarodowa Statystyczna Klasyfikacja Chorób i Problemów Zdrowotnych ICD-10 określa transseksualizm „zaburzeniem identyfikacji płciowej” (F64), w grupie klasyfikacyjnej: „zaburzenia osobowości i zachowania dorosłych".

Diagnoza owego zaburzenia bazuje na zakładanym niedopasowaniu między płcią biologiczną a kulturową. Medykalizacja transseksualizmu związana jest nie tyle z przekraczaniem binarnego systemu płci, ale z utwierdzaniem, że jest to jedyny słuszny i „zdrowy” podział. „Zaburzenia identyfikacji płciowej odzwierciedlają i wzmacniają (...) esencjalistyczną wizję »naturalnych« relacji między kategoriami płci biologicznej (osoba płci męskiej/żeńskiej), tożsamości płciowej (mężczyzna/kobieta) i uzewnętrznianymi cechami płciowymi (męskie/kobiece), patologizując alternatywne konfiguracje płci biologicznej i kulturowej. Nienormatywne sposoby konstruowania 
płci - kobiece osoby płci męskiej (...) [albo] osoby o kobiecym ciele, określające się jako mężczyźni [stają się] przykładami klinicznej »dysforii płciowej«" (Mc Gann 2006: 31-32). Według Anny FaustoSterling (2000) reżim medyczny koncentruje się właśnie na tym, by utrzymać mit istnienia tylko i wyłącznie dwóch płci. Twierdzi ona, że działania medyczne związane z terapią hormonalną oraz operacjami medycznymi są wspierane właśnie dlatego, że legitymizują binaryzm płciowy.

Jak pisze Alicja Strzelecka (2004), lęk związany z odmową możliwości podjęcia leczenia powoduje, że osoby transseksualne - w kontaktach z lekarzami i psychologami - wyolbrzymiają i często przerysowują cechy oraz zachowania typowe dla płci, w kierunku której chcą dokonać korekty. Jeśli nie jesteśmy pewni, co znaczy być kobietą, a co mężczyzną w naszej kulturze, Stefan Hirschauer (1997) proponuje zapytać osoby transseksualne i ich lekarzy, bo wydaje się, że oni to wiedzą najlepiej.

\section{Prymat medycyny}

Transseksualność w Polsce jest zjawiskiem wysoce zmedykalizowanym. Jest tak głównie ze względu na stosowane procedury diagnozy, ale również w związku z tym, że postęp medyczny daje szereg narzędzi medycznych umożliwiających korektę płci, co w naszych realiach związane jest z oddaniem prymatu medycynie w decydowaniu o tym, kto i na jakich warunkach może z tych udogodnień skorzystać (Grzeszczak 2015: 52-66).

W szeregu analiz dotyczących korekty płci zwraca się uwagę na zawiły i nieco absurdalny (np. pozwanie przed sąd rodziców) proces prawnego uzgadniania płci. Uważam jednak, że - nie bagatelizując wagi legislacji korekty płci dla osób zainteresowanych - dyskurs prawny jest na usługach medycznego, by legitymizować medyczne diagnozy i ustanawiać jako jedyne słuszne medyczne osądy, które są sytuowane jako obiektywne, w odróżnieniu od subiektywnych „niepewności" osób zainteresowanych korektą płci². Próba obiektywizacji, a zatem diagnozy, jest podważaniem wiarygodności człowieka. To, co odczuwa i czego pragnie osoba transseksualna musi być "sprawdzone” za pomocą szeregu testów, rozmów i badań medycznych (Czub 2002), których „pomyślne przejście” potwierdzi, że osoba faktycznie może dokonać korekty płci, a zatem by zostać określoną jako znajdującą się „poza” normą i mieć prawo „odzyskać” normę (por. Dynarski 2014: 4).

\footnotetext{
${ }^{2}$ Rozpoczęcie kuracji hormonalnej pozwala uwiarygodnić w sądzie transseksualność, ale operacje na zewnętrznych i wewnętrznych narządach płciowych z punktu prawnego można przebyć dopiero po decyzji sądu (zob. Kryszk, Kłonkowska 2012: 242).
} 
Sytuacja osób transseksualnych jest o tyle odmienna od "zwykłej" relacji z lekarzem, że taka osoba przychodzi do lekarza z gotową diagnozą, odbiera tym sposobem lekarzowi władzę osądu i definiowania sytuacji, więc owa indywidualna diagnoza jest podważana i osoba, która staje się pacjentem, musi "obronić" swoje stanowisko, wyjaśnić, jakie są powody, że tak właśnie twierdzi. By to osiągnąć, jednostka musi odwołać się do medycznych "obiektywnych" standardów definiowania transseksualności, które nie uznają wieloznaczności i niepewności. Osoba transseksualna musi zatem nauczyć się owych standardów, często do nich dopasować swą narrację „zaburzenia”, czyli postępować według pewnego oczekiwanego scenariusza, który zapewni uzyskanie oczekiwanej diagnozy (Hines 2008: 209-210). Obrona jest możliwa tylko przez zastosowanie medycznego języka, którego dostarcza seksuologia, i za pomocą którego osoby transseksualne mają opisać swe doświadczenia - w tym seksualne, przeżycia z uwzględnieniem elementów, które "powinny” się pojawić, a historia musi być spójna i przekonywująca. Tylko bowiem takie narracje legitymizują transseksualną tożsamość. Viviane Namaste (2000: 192) podkreśla, że osoby transseksualne czytają to, co piszą o nich psychiatrzy, w związku z czym wykorzystują kliniczne założenia i na ich bazie prezentują swoje "klasyczne" narracje transseksualisty, by uzyskiwać opiekę zdrowotną i dostęp do technologii medycznej. Jednocześnie muszą "uznać" swą patologię.

Takie postępowanie może łączyć się z powielaniem mitów związanych z transseksualizmem, miedzy innymi przekonaniem, że osoby transseksualne mają wyłącznie heteroseksualną orientację, podczas gdy transseksualizm nie determinuje orientacji seksualnej w jednoznaczny sposób (Bieńkowska 2012: 51; Kryszk, Kłonkowska 2012: 234)³ , a ponadto jest ona mniej stabilna i może zmienić się wraz z wejściem w nową rolę płciową (Czub 2002). Jednak część osób transseksualnych może przyjmować medyczne kategorie i następnie konstruować swoje biografie przez odniesienie do owych kategorii i pojęć. Tym sposobem medyczne terminy ujarzmiają, to one wkładają w usta jedyny słuszny język, opis i znaczenia.

\footnotetext{
${ }^{3}$ Badania ilościowe przeprowadzone wśród osób transpłciowych przez Kryszk i Kłonkowską (2012: 234) wskazały, że w badanej grupie 37\% osób zadeklarowało heteroseksualną orientację seksualną (w odniesieniu do płci, z którą się identyfikuje), jako biseksualne określiło się 31,5\% osób, z kolei jako homoseksualne uważa się 21,3\% osób.
} 


\section{Relacja z lekarzem i znaczenie interwencji medycznych}

Istotnym dylematem, który pojawił się w kontekście transseksualizmu było to, czy należy dostosowywać poprzez działania psychiatryczne duszę do ciała, czy chirurgicznie ciało do duszy (Hirschauer 1997). Początkowo nacisk był kładziony na szereg terapii, które miały "leczyć duszę", dziś "naprawia się" raczej ciała. Nie zmienia to jednak faktu, że nadal te same osoby, czyli seksuolodzy, psychiatrzy i psychologowie oraz lekarze medycyny podejmują decyzje umożliwiające zmiany i je wdrażają.

Pat Califia (1997: 80) twierdzi, że osoby transseksualne są „ulubieńcami” seksuologów i lekarzy, ponieważ mogą być "uleczeni” dzięki zastosowaniu terapii hormonalnej i operacjom medycznym. Interesujące są jednak standardy diagnostyczne w procedurze selekcji kandydatów do operacji. Lekarze i psychologowie, pełniący role strażników (gatekeepers) w procesie medykalizacji transseksualności, dobierają dobrze „rokujących" pacjentów, którzy współpracują z medycznym projektem. Według Hirschauera (1997) wynika to przede wszystkim z faktu, że lekarz ryzykuje swą reputację, „zezwalając” pacjentowi na „migracje genderową” i chce swój medyczny autorytet obronić przez pomyślne zakończenie leczenia. „Pogorszenie” mogłoby stanowić zagrożenie dla legitymizacji udziału medycyny w tym procederze. Ponadto Hirschauer (1997) wskazuje, że w założeniach standardy diagnostyczne mają chronić pacjentów przed niewłaściwym leczeniem. Warto jednak zastanowić się, na czym polega rozróżnienie na dobre i niewłaściwe leczenie. Z perspektywy medyków chodzi o wątpliwości związane z podjęciem leczenia osób po diagnozie, która pozwoli rozróżnić "fałszywych" i „prawdziwych" transseksualistów. Niewłaściwe leczenie nie wiąże się zatem z obawami o jakość realizowanych interwencji medycznych ${ }^{4}$, a raczej o ich zasadność. Operacje chirurgiczne umożliwiające korektę płci uwznioślane są przez system diagnostyczny, który jest jedynym narzędziem pozwalającym na realizację operacji chirurgicznej, która wydaje się być nagrodą za pomyślnie przebrnięte liczne testy.

Medycy są strażnikami porządku, wpuszczają tych, którzy dostosują się do normatywnych reguł i uznają diagnozę za słuszną, potwierdzającą binaryzm, ale dodatkowo sami pokrywają koszty medycznych interwencji. Droga prawna związana z korektą płci metrykalnej jest ściśle związana z medycznymi diagnozami. Osoby transseksualne podporządkowują się lekarzom, przestają być

\footnotetext{
${ }^{4}$ Jak podkreśla Dynarski (2012: 285-286) w Polsce leczenie hormonalne odbywa się zwykle bez konsultacji endokrynologicznej i osoby zdobywają informacje na własną rękę, podczas gdy leczenie hormonalne jest procesem wiążącym się z ryzykiem niekorzystnych następstw (Breska-Kruszewska, Rachoń 2014: 169-173).
} 
"osobami" - stają się „pacjentami”, którzy podlegają procedurom i są uprzedmiotawiani, na co godzą się często z obawy przed negatywną opinią lekarską (Grzejszczak 2014: 49).

Według Namaste (2000: 190) możemy obserwować konflikt między osobami transseksualnymi a psychologami i lekarzami, który wzmacnia instytucjonalne wykluczenie osób transseksualnych i transgenderowych. Warto także zaznaczyć, że część osób, które nie dążą do interwencji medycznych, a jedynie do korekty oznaczenia płci w dokumentach jest również zmuszana do poddania się medycznej kontroli (Dynarski 2015) ${ }^{5}$. Bez diagnozy i działań medycznych, ujarzmienia, bez naznaczenia jednostki jako pacjenta, a zatem chorego, którego trzeba leczyć, który znalazł się poza normą - nie ma możliwości korekty płci w dokumentach.

\section{Obszary demedykalizacji transseksualności}

Jak podkreśla Califia (1997: 224), dziś osoby transseksualne nie są biernymi biorcami pomocy, jaką zechcą dać im lekarze, seksuolodzy i psychiatrzy, którzy funkcjonują jako strażnicy korekty płci, ale coraz częściej podważają ich autorytet. W latach dziewięćdziesiątych XX wieku w Stanach Zjednoczonych zaczęto stosować termin transpłciowość, w opozycji do medycznych patologizujacych konotacji, w celu opisu tożsamości społeczno-politycznej (Dębińska 2014: 53, Dynarski 2010: 67). Zaczęto również kwestionować istniejące kryteria diagnostyczne, czyli normatywne narracje historii życia osób transpłciowych (Stone 1996: 280-304) i opisywać transpłciowość "W kategoriach transgresji krytykującej dotychczas bezrefleksyjnie przyjmowany binaryzm płciowy. W transpłciowym środowisku definicje przestają mieć znaczenie, zaś medycyna i diagnozy umożliwiające późniejszą korektę ciała i/lub legalnego statusu zaczynają być traktowane jako środek pomocniczy i pośredni, nie zaś jako podstawa orzekania, czy jest się osobą trans, czy nie" (Dynarski 2010: 67). Powstały inicjatywy i organizacje, jak: Global Action for Trans Equality (GATE), Stop Trans Pathologization (STP) and Transgender Europe (TGEU), które proponują zmiany w klasyfikacji lub depatologizacji transseksualności. Jedną z ich propozycji jest skreślenie tzw. „zaburzeń tożsamości płciowej” z klasyfikacji medycznej i zastąpienie pozycją „zjawisk niebędących zaburzeniami, jednak wymagającymi medycznych interwencji" (Dynarski 2010: 66). W projekcie ICD 11 pojawiło się pojęcie "gender incongruence", które Wiktor Dynarski proponuje tłumaczyć jako „niespójność płciowa”, które ma pojawić się w kategorii: „Conditions related to sexual health". Jest

\footnotetext{
${ }^{5}$ Badania ilościowe przeprowadzone wśród osób transpłciowych przez Kryszk i Kłonkowską (2012: 244) wskazały, że w badanej grupie 5,5\% osób czuło się zmuszane do poddania kuracji, czy interwencji medycznej przez lekarzy lub wymogi prawne. Według Autorek badań nacisk wiązał się z możliwością dokonania prawnej korekty płci.
} 
to istotna zmiana, gdyż odsuwa skojarzenie transseksualności z chorobą psychiczną i przyczynia się do zmniejszenia stygmatyzacji osób transseksualnych.

Califia (1997: 260-261) twierdzi, że demedyklizacja transseksualności stwarza pewien dylemat. Ze względu na kulturowy dyktat narządów płciowych od osób transseksualnych oczekuje się, że poddadzą się chirurgicznej operacji narządów płciowych i wiele osób podejmuje szereg działań, by podtrzymać status "chorego". Demedykalizacja transseksualności mogłaby spowodować ograniczenie ilości operacji chirurgicznych i zwiększenie ich kosztów.

Zaklasyfikowanie transseksualności jako „zaburzenia”, które jest diagnozowane, a następnie wymaga „leczenia" patologizuje i poprzez medycznie uzasadnienie piętnuje, przesuwając jednostkę na margines. Ponadto ze względu na klasyfikację medyczną łączy ją z chorobą psychiczną, a zatem powoduje społeczny lęk, ale także może powodować u osób transseksualnych dyskomfort. Z drugiej strony, istnienie jednostki chorobowej daje osobom, które tego pragną, możliwość medycznej korekty płci i może być pomocne w samoakceptacji czy rozmowie z rodziną, bo skoro "to się leczy. To świetnie" (Dynarski 2015).

\section{Seksualność transmężczyzn w kulturze fallocentryzmu}

W odniesieniu do transseksualności trudno skupić się wyłącznie na męskości i męskiej seksualności w związku z wpisaną w tę kategorię "migracją genderową” (Hirschauer 1997). Z jednej strony transseksualność łączona jest z płynnością kategorii płci, z drugiej wyraźnie odnoszona do binaryzmu płciowego ${ }^{6}$. Warto jednak zaznaczyć wątek kluczowy, który może wydawać się zamazany ze względu na uwagę, jaką poświęciłam samemu procesowi medykalizacji transseksualności, a zatem kwestię medykalizacji seksualności transmężczyzn. Tematyka ta, choć złożona, wydaje się niezwykle prosta, jeśli spojrzymy na nią z perspektywy medycznej.

Dyskurs medyczny, uwznioślając binarny podział ciał, seksualności, orientacji seksualnej wydziela w obszarze transseksualności wyraźną linię demarkacyjną i podkreśla binaryzm nie tylko w kontekście ciał, ale też seksualności osób i ich orientacji seksualnej. Medyczna perspektywa wydaje się pomijać

\footnotetext{
${ }^{6}$ Binaryzm ten jest widoczny przede wszystkim w niektórych sposobach autoprezentacji osób transseksualnych, które umiejscawiają swe doświadczenia w opisanych i oczekiwanych przez „ekspertów” „wzorach”. Małgorzata Bieńkowska tę fasadę, która ukrywa prawdziwe doświadczenia i odczucia osób transseksualnych, określa mianem "oficjalnej maski transseksualisty" (Bieńkowska 2012: 50-51).
} 
kwestie związane z seksualnością osób transseksualnych i wpisywać je wyłącznie w binarny model stosunku seksualnego, gdzie zatem najistotniejsza jest korekta narządów płciowych, co wspiera binarny i "właściwy" porządek. O orientacji seksualnej osób transseksualnych raczej się nie wspomina, ponadto sam proces „medycznej diagnozy" wymuszą jednoznaczne identyfikowanie się z daną płcią i jako oczywiste traktuje pożądanie drugiej płci.

Transseksualność utożsamiana jest przede wszystkim z cielesnością, a w dyskursie medycznym z „niewłaściwym” ciałem, które jest jednak ściśle związane z kwestią seksualności. Medycyna posiada narzędzia, które pozwalają „przywrócić” ciała osobom transseksualnym, a sięga po nie głównie dlatego, że działania te wzmacniają binarny podział i słuszność tegoż podziału. Z tej perspektywy podkreśla się też niechęć lub wręcz obrzydzenie do swojego ciała, w tym genitaliów, choć w rzeczywistości mniejszość (oczywiście z różnych względów) osób - zwłaszcza mężczyzn transseksualnych decyduje się na operację narządów płciowych. Czy z perspektywy medycznej mężczyzna może zatem być mężczyzną, jeśli nie posiada penisa? Mężczyźni transseksualni, którzy nie chcą przejść tego etapu operacji, zaburzają porządek, gdyż wymykają się binarnemu podziałowi i prymatowi narządów płciowych w naszej kulturze, w związku z czym wygodne wydaje się wówczas założenie, że tylko koszty są barierą i blokują możliwość poddania się operacji. Jednocześnie medyczne rozwiązania, bazując na zakładanej niechęci osób transseksualnych do posiadanych od urodzenia genitaliów, często nie uwzględniają aspektów związanych z przyjemnością seksualną. Przyjemność seksualna i jej odczuwanie jest pomijane milczeniem, nie podejmuje się przykładowo wątku masturbacji, jakby seksualność i potrzeby seksualne oraz inne formy realizowania seksualności niż genitalna nie istniały, a korekta narządów płciowych (tylko dla faktu posiadania takich narządów, bez uwzględnienia ich funkcjonalności) traktowana jako oczywiste pragnienie każdej osoby. Niechęć do korekty narządów płciowych z różnych względów, w tym ze względu na obawy związane z brakiem odczuwaniem przyjemności seksualnej - nie są z perspektywy medycznej wystarczającym argumentem. Biologiczna całkowita zmiana, która potwierdza słuszność binarnego podziału, jest uznawana za jedyny dobry wybór. Wszelkie inne formy uzyskiwania przyjemności seksualnej niż heteroseksualny stosunek są pomijane, są wstydliwe. Powszechnie akceptowana jest chęć poddania się operacji rekonstrukcji narządów płciowych, w innej sytuacji jednostka pozostaje gdzieś „pomiędzy”, gdzie trudno przyznać prawa do dowolnej ekspresji seksualnej i relacji seksualnych. 
Wielu transmężczyzn nie decyduje się na operację rekonstrukcji penisa, powodem są niechęć do przejścia takiej operacji (wbrew rozpowszechnianemu w dyskursie medycznym obrzydzeniu do narządów posiadanych od urodzenia), odsuwanie w czasie decyzji (przy jednoczesnym funkcjonowaniu w związkach i podtrzymywaniu relacji seksualnych) czy wysokie koszty operacji, która mogłaby przynieść zadawalający efekt. Medycznie podkreślany prymat jednoznaczności płciowej, zwłaszcza w kontekście genitaliów, uwzniośla realizację operacji rekonstrukcji penisa, które są jednak blokowane znacznymi nakładami finansowymi, jakie trzeba ponieść. Tak więc kluczowe - już w samym procesie diagnozy - jest "przywracanie” ciała we wszystkich wymiarach, przy jednoczesnym blokowaniu dostępu do korekt dających (osobom, które tego pragną i identyfikują) ciało w pełni "jednoznaczne”. Dochodzi zatem do patologizowania i marginalizowania ciał transmężczyzn, które nie są jednoznacznie męskie - czyli nie posiadają penisa. Penis jest tu symbolem, a nie tylko "narzędziem” uzyskiwania i dawania przyjemności seksualnej, lecz jednak inne sposoby doświadczeń seksualności i przyjemności seksualnej nie są traktowane jako wystarczające.

Mamy tu do czynienia z paradoksem. Żyjemy w kulturze zorientowanej na przyjemność genitalną (gdzie w centrum jest penis), a jednocześnie dochodzi do próby odbierania lub unieważniania przyjemności seksualnej, jaką transseksualny mężczyzna może uzyskiwać dzięki sprawnemu penisowi. Seksualność wychodząca poza przyjemność płynącą z orgazmu i pobudzenia genitaliów jest bowiem z góry traktowana jako mniej istotna i mniej znacząca. Penis jako symbol potwierdzający męskość i binaryzm płciowy ma stanowić element ciała transmężczyzny, lecz jego sprawność i możliwość uzyskania przyjemności seksualnej nie wydaje się być już kwestią kluczową. Potwierdza to między innymi często niska jakość operacji, która ogranicza się to posiadania protezy narządów płciowych, podczas gdy operacja umożliwiająca odczuwanie przyjemności seksualnej jest niezwykle droga. Transmężczyzna ma być zadowolony z samego faktu posiadania penisa, ale gwarancja jego sprawności nie jest już traktowana jako tak istotna. Ponownie penis stał się tu kwestią rozważań, ale chcę odnieść tę kwestię do naszej rzeczywistości, w której przekonuje się nas, że najważniejsza jest przyjemność genitalna.

Seksualność transmężczyzn jest zawężana do medycznych standardów. Zmiana jest oczekiwana jako zmiana kompletna, niepodlegająca wątpliwościom, jednoznaczna zarówno w procesie korekty ciała, jak i sposobie myślenia o własnej tożsamości seksualnej. Patologizowane są sytuacje 
niedążenia do korekty narządów płciowych, wręcz powątpiewa się w „normalnośćc takich sytuacji, gdyż są one niejednoznaczne i wymykają się zarówno binarnemu podziałowi ciał i obiektów pożądania, jak i seksualności sprowadzanej usilnie do aktu penetracji pochwy przez penisa, unieważniając inne formy przyjemności seksualnej. Spycha na margines męskości mężczyzn, którzy nie chcą lub nie mogą poddać się korekcie narządów płciowych. Ze względu na kulturowy dyktat narządów płciowych traktuje się ich jako niekompletnych mężczyzn, gdzie biologiczny wymiar stawiany jest na piedestale, a każda niejednoznaczność wobec medycznych standardów patologizowania.

\section{Zakończenie}

Powyższa analiza - mająca na celu wskazanie drogi, jaka prowadziła do medykalizacji męskiej seksualności i wybranych wątków związanych z seksualnością, które poddawane zostają temu procesowi - stanowi jedynie zarys jakże rozległej problematyki. Szereg kwestii zostało zaledwie zasygnalizowanych, by wskazać, jak rozległe obszary naszego życia seksualnego podległy medykalizacji, a dodać można by jeszcze kwestie biomedykalizacji czy genetyzacji. Medykalizacja jest terminem, który sam w sobie niesie podejście krytyczne, nie mam jednak wątpliwości, że dyskurs medyczny patologizuje seksualność. Z tego też względu zdecydowałam się, pisząc o seksualności mężczyzn, wyjść od szerszego opisu zjawiska medykalizacji homoseksualności czy transseksualności, gdyż uznałam, że jest to istotne tło. Przeciwieństwem medycznego podejścia do seksualności jest przyjęcie różnorodności w kwestii seksualności, przez co uwzględnia się różnorodność kulturową, psychologiczną, związaną z różnymi etapami życia, a także dostrzegającą szeroki kontekst społeczny (Tiefer 2012: 314). Czy zatem medykalizacja jest procesem niebezpiecznym? Medykalizacja seksualności stanowi element współczesnych przemian, bądź rekonstruowania męskości i kobiecości, i z pewnością zagraża wielości, gdyż trudno oczekiwać, by wielość wpisywała się $\mathrm{w}$ normę, a zatem jest narzędziem sankcjonującym jedyną słuszną seksualność, czy raczej heteroseksualność. Dyskurs medyczny ujarzmia seksualność, nadzoruje ją, lecz nie jest to odpowiedź ostateczna, medykalizacja jest bowiem procesem. Warto zatem nie zgubić kontekstu społeczno-kulturowego, gdyż seks nie jest zjawiskiem biologicznym, „nie rodzimy się jako istoty seksualne, lecz raczej uczymy się nimi być, i dzieje się tak jedynie w tych społeczeństwach, które wynalazły ideę »seksualności«" (Seidman 2012: 75). 
Jestem świadoma ograniczeń i braków w powyższych analizach. Przede wszystkim zastosowałam medyczne określenia wspierające dyskurs medyczny oraz próbowałam odnieść się do mężczyzn „W ogóle" - co nie jest możliwe. Nie potrafiłam też w tak krótkim tekście podjąć wielu wątków, które wymagają uwagi. Nie zdołałam wystarczająco przedstawić historycznej perspektywy seksualności, także wątek biseksualności - zaledwie zasygnalizowany - wymaga szerszego opisu. Z pewnością warto też poszerzyć wątek postrzegania/realizowania seksualności przez transmężczyzn, który został tu odniesiony wyłącznie do kulturowych standardów falliczności i perspektywy medycznej. Brakiem, a jednocześnie obszarem wartym dalszych analiz, jest niewystarczające uwzględnienie perspektywy intersekcjonalnej, która pozwoli nie mówić o męskiej seksualności w ogóle, lecz o seksualności mężczyzn, których gender przecina się z innymi wymiarami życia. Kategorie różnicujące, takie jak klasa, etniczność czy niepełnosprawność nie pojawiły się w tekście, a wątek męskiej seksualności w starości został zaledwie zasygnalizowany. Zdaję sobie sprawę z faktu, że warto poszerzyć analizy o dodatkowe wątki, gdyż mężczyźni, którzy jako tacy się określają, nie są grupą jednolitą zarówno pod względem seksualności, indywidualnych cech osobowości, jak i przynależności do różnych grup, między innymi etnicznych, wyznaniowych, są w różnym wieku, różny może być poziom ich sprawności. Pisząc artykuł, zdałam sobie sprawę, że nie jest możliwe napisanie tekstu o medykalizacji męskiej seksualności w ogóle, zawsze byłby to tekst nieuwzględniający złożoności problemu, dlatego spojrzałam na ten problem, wybierając pewne wątki, które często przeszły z dyskursu medycznego do naszego codziennego pojmowania świata.

\section{BIBLIOGRAFIA}

Abraham, John. 2010. The sociological concomitants of the pharmaceutical industry and medications. W: (red.) Bird, Chloe, Conrad Peter, Fremont Allen M., Timmermans Stefan. Handbook of medical sociology. Nashville: Vanderbilt U.P, s. 290-308.

Barker, Kristin. 2009. Medicalization, multiplication of disease, and human enhancement. W: "Salute e Società" 8, s. 99-122.

Bell, Susan E., Figert, Anne E. 2012. Medicalization and pharmaceuticalization at the intersections: Looking backward, sideways and forward. W: "Social Science \& Medicine” 75, s. 775-783.

Bieńkowska, Małgorzata, 2012. Transseksualizm w Polsce. Wymiar indywidualny i spoteczny przekraczanie binarnego systemu ptci. Białystok: Wydawnictwo Uniwersytetu w Białymstoku.

Breska-Kruszewska, Justyna, Rachoń, Dominik. 2014. Medyczne aspekty transptciowości. Rozpoznanie i postępowanie lecznicze. W: (red.) Kłonkowska, Anna M., Bojarska, Katarzyna. Psychospoteczne, prawne i medyczne aspekty transptciowości. Gdańsk: Wydawnictwo Uniwersytetu Gdańskiego, s. 165-177. 
Busfield, Joan. 2010. A pill for every ill': Explaining the expansion in medicine use. W: „Social Science \& Medicine" 70, s. 934-941.

Cacchioni, Thea, Tiefer, Leonore. 2012. Why medicalization? Introduction to the special issue on the medicalization of sex. W: „Journal of Sex Research" 49, s. 307-310.

Califia, Pat. 1997. Sex Changes: The Politics of Transgenderism. San Francisco: Cleis.

Clarke, Adele E., Shim, Janet K., Mamo, Laura, Fosket, Jennifer Ruth, Fishman, Jennifer R. 2003. Biomedicalization: Technoscientific Transformations of Health, Illness, and U.S. Biomedicine. W: „American Sociological Review” 68, s. 161-194.

Conrad, Peter, Angell, Alison. 2004. Homosexuality and remedicalization. W: "Society" 41, s. 32-39.

Conrad, Peter, Schneider, Joseph W. 1992. Deviance and medicalization. From badness to sickness. Philadelphia: Temple University Press.

Conrad, Peter. 1992. Medicalization and Social Control. W: „Annual Review of Sociology” 18, s. 209232.

Conrad, Peter. 2006. Up, down, and sideways. W: „Society” 43, s. 19-20.

Conrad, Peter. 2005. The shifting engines of Medicalization. W: „Journal of Health and Social Behavior" 46, s. 3-14.

Czub, Marcin. 2002. Rola psychologa i psychoterapii w transseksualizmie. W: (red.) Kuczyńska, Agnieszka. Zrozumieć płeć. Studia interdyscyplinarne. Wrocław: Wydawnictwo Uniwersytetu Wrocławskiego.

Dębińska, Maria. 2014. Trzeba zmienić spoteczeństwo. Seksuologia i transseksualizm w późnym PRL. W: „Zeszyty Etnologii Wrocławskiej” 1, s. 51-73.

Domaradzki, Jan. 2010. Polityka ptci: „staba pteć", medycyna i kontrola spoteczna. W: „Nowiny Lekarskie" 79, s. 464-473.

Dynarski, Wiktor. 2010. Tematyka transpłciowości w wybranych publikacjach oraz jej usytuowanie we wspótczesnych dyskursach akademickich. W: (red.) Lewe, Agata, Raport o homo-, biseksualności i transptciowości w polskich podręcznikach akademickich. Warszawa: Kampania przeciw homofobii, s. 65-77.

<http://www.kph.org.pl/publikacje/raport2010_podreczniki_akademickie.pdf >; dostęp: 14.01.2015.

Dynarski, Wiktor, Kłonkowska, Anna. 2012. Stowniczek. W: (red.) Makuchowska, Mirosława, Pawlęga, Michał. Sytuacja społeczna osób LGBT. Raport za lata 2010 i 2011. Warszawa: Wydawnictwo $\mathrm{KPH}$.

Dynarski, Wiktor. 2012. Strażnicy ptciowych bram - gatekeeping w kontekście doświadczeń osób korygujacych pteć w Polsce. W: (red.) Makuchowska, Mirosława, Pawlęga, Michał. Sytuacja społeczna osób LGBT. Raport za lata 2010 i 2011. Warszawa: Fundacja Przeciw Homofobii, Stowarzyszenie Lambda, Fundacja Trans-Fuzja, s. 280-294

Dynarski, Wiktor. 2014. Poland's Route To a Transgender (R)evolution. W: Gender Recognition in Poland. A Report on Court and Administrative Procedures!. Fundacja Trans-Fuzja, Polskie Towarzystwo Prawa Antydyskryminacyjnego.

http://transfuzja.org/download/publikacje/gender_recognition_in_poland.pdf; dostęp: 14.01.2015. 
Dynarski, Wiktor. 2015. Gdy przestaniemy być transseksualni, http://dynarski.pl/post/100528174275/gdy-przestaniemy-byc-transseksualni; dostęp: 14.01.2015

Engelhardt, H. Tristram. 1974. The disease of masturbation: values and the concept of disease. W: "Bulletin of the History of Medicine" 48, s. 234-248.

Epstein, Steven. 2003. Sexualizing governance and medicalizing identities: The emergence of "statecentered" LGBT health politics in the United Stated. W: "Sexualities" 6, s. 131-171.

Eunjung, Kim. 2010. How much sex is healthy? The pleasures of asexuality. W: (red.) Metzl, Jonathan M., Kirkland, Anna. Against health: How health became the new morality. New York: New York University Press, s. 157-168.

Fausto-Sterling, Anne. 2000. Sexing the Body: Gender Politics and the Construction of Sexuality. New York: Basic Books.

Foulcault, Michael. 1998. Trzeba bronić społeczeństwa. Tłum. Małgorzata Kowalska. Warszawa: Fundacja Aletheia.

Foulcault, Michael. 2000. Historia seksualności. Tłum. Bogdan Banasik, tadeusz Komendant I Krzysztof Matuszewski. Warszawa: Czytelnik.

Freidson, Eliot. 1970a. Profession of Medicine. A Study of the Sociology of Applied Knowledge. New York: Harper \& Row Publishers.

Freidson, Eliot. 1970b. Professional Dominance. The Social Structure of Medical Care. Chicago: Aldine Publishing Company.

Greenberg, David F. 1998. The construction of homosexuality. Chicago: University Chicago Press.

Grzeszczak, Roman. 2015. Transptciowość a opieka zdrowotna w Polsce - raport z badań. W: (red.) Dynarski, Wiktor, Jąderek, Izabela. Transptciowość a opieka zdrowotna w Polsce raport z badań . Warszawa: Fundacja Trans-Fuzja, s. 9-74.

http://transfuzja.org/download/publikacje/transplciowosc_a_opieka_zdrowtona_w_polsce.pd f; dostęp: 12.03.2015.

Gupta, Kristina. 2011. "Screw health": Representations of sex as a health-promoting activity in medical and popular literature. W: „Journal of Medical Humanities" 32, s. 127-140.

Halfmann, Drew. 2011. Recognizing Medicalization and Demedicalization: Discourses, Practices and Identities. W: „Health" 16(2), s. 186-207.

Hines, Sally. 2008. (Trans)formacja gender: zmiana społeczna i transgenderowe obywatelstwo. Tłum. Małgorzata Maciejewska. W: (red.) Oleksy, Elżbieta. Tożsamość i obywatelstwo w społeczeństwie wielokulturowym. Warszawa: PWN, s. 209-210.

Hirschauer, Stefan. 1997. The Medicalization of Gender Migration, "The International Journal of Transgenderism" 1. <http://www.symposion.com/ijt/ijtc0104.htm>; dostęp 14.01.2015.

ICD-11 Beta Draft, <http://apps.who.int/classifications/icd11/browse/l-m/en>; dostęp: 02.07.2015.

Segal, Judy Z. 2012. The sexualization of the medical. W: "Journal of Sex Research" 49, s. 369-378.

Katz, Jonathan N. 1995. The invention of heterosexuality. New York: Dutton.

Kinsey, Alfred, Pomeroy, Wardell B., Martin, Clyde E. 1948. Sexual Behavior in the Human Male. Philadelphia: W.B. Saunders. 
Kirkman, Allison. 2005. Ageing and sexuality: The final frontier for positive ageing?. W: (red.) Hawkes, Gail, Scott John. Perspectives in human sexuality. Melbourne: Oxford University Pres, s. 104118.

Kochanowski, Jacek. 2004a. Czy gej jest mężczyzną? Przyczynki do teorii postpłciowości. W: (red.) Radkiewicz, Małgorzata. Kraków: Wydawnictwo RABID, s. 103-115.

Kochanowski, Jacek. 2004b. Fantazmat zróżnicowany. Socjologiczne studium przemian tożsamości gejów. Kraków: Universitas.

Kryszk, Kinga, Kłonkowska, Anna. 2012. Sytuacja społeczna osób transptciowych. Analiza danych z badania ankietowego. W: (red.) Makuchowska, Mirosława, Pawlęga, Michał. Sytuacja spoteczna osób LGBT. Raport za lata 2010 i 2011. Warszawa: Fundacja Przeciw Homofobii, Stowarzyszenie Lambda, Fundacja Trans-Fuzja, s. 219- 279.

Loe, Mieka. 2001. Fixing broken masculinity: Viagra as a technology for the production of gender and sexuality. W: "Sexuality \& Culture" 5, s. 97-125.

MacDougall, Robert. 2006. Remaking the Real men: Erectile dysfunction palliatives and the social reconstruction of the male heterosexual life cycle. W: „Society \& Culture” 10, s. 59-90.

Maines, Rachel P. 1999. The technology of orgasm: 'Hysteria', the vibrator, and women's sexual satisfaction. Baltimore, London: The Johns Hopkins University Press.

Majka, Rafał. 2015. Poza „bezpieczniejszym seksem” - bareback i fetyszyzacja seksu bez zabezpieczenia. W: „InterAlia” 10 (2015), s. 195-216.

Marshall, Barbara L. 2012. Medicalization and the refashioning of age-related limits on sexuality. W: "Journal of Sex Research" 49, s. 337-343.

Marshall, Barbara, Katz, Stephen. 2002. Is the functional "normal"? Aging, sexuality and the biomarking of successful living. W: "History of the Human Sciences" 17, s. 53-75.

Masters, William H., Johnson, Vicroria E. 1966. Human sexual response. Boston: Little, Brown.

Maturo, Antonio. 2012. Medicalization: current concept and future direction in a bionic society. W: „Mens Sana Monographs" 10, s. 122-133.

Mc Gann, P.J. 2006. Healing (disorderly) desire. Medical-therapeutic regulation of sexuality. W: (red.) Seidman, Steven, Fisher, Nancy, Meeks, Chet. Introducing the new sexuality studies. New York: Routledge, s. 390-402.

Messerschmidt, James W. 1993. Masculinities and crime: Critique and reconceptualization of theory. Lanham: Rowman and Littlefield.

Meyerowitz, Joanne. 2002. How sex changed. A history of transsexuality in United States. Harvard University Press Cambridge: Massachusetts London.

Murphy, Peter F. 2002. Studs, tools and the family jewels: Metaphors men live by. Madison: University of Wisconsin Press.

Namaste, Viviane K. 2000. Invisible Lives: The Erasure of Transsexual and Transgendered People. Chicago: $U$ of Chicago Press.

Parsons, Talcott. 2009. System społeczny. Tłum. Michał Kaczmarczyk. Kraków: Zakład Wydawniczy Nomos. 
Plummer, Ken. 2005. Male Sexualities. W: (red.) Kimmel, Michael S., Hearn, Jeff R., Connell Reawen. W: Handbook of Studies on Men and Masculinities. Thousand Oaks-London-New Delhi: Sage Publications, s. 178-195.

Potts, Anne. 2000. 'The essence of hard on': hegemonic masculinity and the culture construction of 'erectile dysfunction'. W: „Men and Masculinities" 3, s. 85-103.

Potts, Anne. 2002. The Science/Fiction of Sex: Feminist Deconstruction and the Vocabularies of Heterosex. New York: Routledge.

Pużyński, Stanisław. 2007. Choroba psychiczna - problemy z definicja oraz miejscem $w$ diagnostyce $i$ regulacjach prawnych. W: „Psychiatria Polska” 3: 299-308.

Robinson, Paul. 1976. The modernization of sex. New York: Harper \& Row.

Segal, Judy Z. 2012. The sexualization of the medical. W: „Journal of Sex Research" 49, s. 369-378.

Segal, Lynne. 1994. Straight sex: the politics of pleasure. London: Virago.

Seidman, Steven. 2012. Społeczne tworzenie seksualności. Tłum. Paweł Tomanek. Warszawa: PWN.

Grzeszczak, Roman. 2014. Transgender under research. W: Gender Recognition in Poland. A Report on Court and Administrative Procedures!. Fundacja Trans-Fuzja, Polskie Towarzystwo Prawa Antydyskryminacyjnego,

http://transfuzja.org/download/publikacje/gender_recognition_in_poland.pdf; dostęp 14.01.2015.

Stone, Sandy. 1996. The "Empire" strikes back. A posttranssexual manifesto. W: (red.) Straub, Kristina, Epstein, Julia. Body guards. The cultural politics of sexual ambiguity. New York: Routledge, s. 280-304.

Stryker, Susan. 2008a. Transgender history. Seal Press: Berkeley.

Stryker, Susan. 2008b. Transgender history, homonormativity and disciplinarity. W: "Radical History Review" 100, s. 145-157.

Strzelecka, Alicja. 2004. Transseksualizm w procesie przekraczania barier. W: (red.) Kuczyńska, Alicja, Dzikowska Elżbieta K. Zrozumieć pteć. Studia interdyscyplinarne t. II, Wrocław: Wydawnictwo Uniwersytetu Wrocławskiego.

Tiefer, Leonore. 1989. In Pursuit of the Perfect Penis. The Medicalization of Male Sexuality. W: (red.) Kimmel Michael S. Changing Men. New Directions in Research on Men and Masculinity. Newbury Park-London-New Delhi: Sage Publications, s. 165-184.

Tiefer, Leonore. 1994. The Medicalization of Impotence: Normalizing Phallocentrism. W: "Gender \& Society" 8, 3, s. 363-377.

Tiefer, Leonore. 1996. The medicalization of sexuality: conceptual, normative, and professional issue. W: „Annual Review of Sex Research” 7, s. 252-282.

Tiefer, Leonore. 2000. Sexology and the pharmaceutical industry: The treat of co-optation, W: „Journal of Sex Research" 37, s. 273-283.

Tiefer, Leonore. 2001. A New view of woman's sexual problems: Why new? Why now?. W: „Journal of Sex Research" 2001, 38, s. 89-96.

Tiefer, Leonore. 2012. Medicalizations and demedicalizations of sexuality therapies. W: „Journal of Sex Research" 49, s. 311-318. 
Tiefer, Leonorre. 1995. Sex is not a natural act and other essays. Westview: Boulder.

Valentine, David. 2007. Imagining transgender. An ethnography of a category. Durham: Duke University Press.

Welch H.G., L.M. Schwartz, S. Woloshin. 2011. Overdiagnosed: Making people sick in the pursuit of health. Boston: Beacon.

Wieczorkowska, Magdalena. 2013. Czy starość jest chorobą? Medykalizacja starości w Polsce. W: „Przegląd Socjologiczny" 62, 2, s. 109-134.

Wienke, Chris. 2006. Sex the natural way: The marketing of Cialis and Levitra. W: (red.) Rosenfeld, Dana, Faircloth, Christopher A. Medicalized masculinities. Philadelphia: Temple University Press, s. 45-64.

Wilkinson, Sue, Kitzinger, Celia. 1994. The Social Construction of Heterosexuality. W: „Journal of Gender Studies" 3, s. 307-316.

Zola, Irving K. 1972. Medicine as an institution of social control. W: „The Sociological Review” 20, s. 487-504.

Zola, Irving K. 1983. Socio-medical inquires. Philadelphia: Temple Univ. Press. 